Negotiated History

\title{
The Historical Record in International Criminal Law and Plea Bargaining
}

\author{
Regina E Rauxloh, University of Surrey, UK
}

"However, there is no peace without justice; there is no justice without truth, meaning the entire truth and nothing but the truth."[1]

\begin{abstract}
One of the most important functions of the international criminal trial is to create an accurate and accessible historical record. This paper analyses to what extent plea bargaining can hinder or facilitate the establishment of the historical record. Drawing on the experience of the ICTY and the ICTR the author makes a number of proposals as to what how and to extent plea bargaining should be used at the ICC to advance rather than to obstruct the historical record.
\end{abstract}

Keywords: International Criminal Law, Plea Bargaining, Historical Record

\section{The Importance of the Historical Record}

" $[\mathrm{I}] \mathrm{t}$ is only the truth that can cleanse the ethnic and religious hatreds and begin the healing process"[2]

The most important function of international criminal justice is the restoration of peace. Indeed, when the United Nations Security Council decided to set up international criminal tribunals for the conflicts in Yugoslavia[3] and Rwanda[4] they could do so only within the mandate of the Security Council under Chapter VII of the United Nations Charter under the assumption that a criminal trial is able to further international peace and security.[5] It is understood that no lasting peace can be achieved without justice for at least some of the violence committed during the conflict. However, justice is not served only by prosecuting and sentencing individual offenders. What is of equal importance is that the roots, background and development, in short, the history of the conflict is exposed. The extent of the victims' suffering, the hierarchy of the power structure, the planning policies and any contributing factors need to be revealed. Only when the truth is established can reconciliation begin.[6] This is particularly true with respect to the role of propaganda in widespread human rights violations. When violence is committed on such a large scale, turning so many civilians not only into victims but also into perpetrators it has to be based on policies which could have been implemented only by the extensive use of propaganda. Propaganda is at the centre of inciting ordinary citizens to exercise unbelievable violence. The victim group needs to be portrayed both as sub-human as well as threatening in order to convince 
a large section of the population to commit or at least allow atrocities against their neighbours and fellow citizens. By establishing a historical record it is hoped to ,pierce the distortions generated by official propaganda"[7] "before the guilty could reinvent the truth".[8] In addition it is important to put names to the central faces behind the atrocities so that individuals rather than groups are blamed. One generally expects "that such a historical record would prevent a cycle of revenge killings and future acts of aggression".[9] Besides its value for healing and reconciliation, truth telling is also essential at the political level to foster the difficult transition from repressive regimes to democracy.[10] A detailed historical record will help the new leadership to make a clear break with the violent history and build a social and political system in which repetition of the conflict will be prevented. Consequently, to establish as accurate as possible a historical record of the roots and the development of the violence is one of the main functions of all international criminal courts.

The term plea bargaining is used here as a generic expression for different forms of agreements between the Defence and the Prosecution (and sometimes even the court). The common denominator is that the defendant admits all or some of the charges in exchange for a lower sentence. Very often there are additional parts to the deal, such as a promise to waive the right to appeal, to provide evidence against other defendants, or to help locating assets etc. In exchange the Prosecution offers to drop some of the charges or to replace them with charges of lesser crimes[11] (charge bargaining) or to recommend a particular sentence or sentencing range to the court (sentence bargaining). Other offers to defendants include dropping charges against a spouse, or special prison conditions, for example the location of imprisonment in a certain country. In the ICTR for example, many defendants would prefer a European prison not only because often the families of defendants of high rank have relocated in Europe but moreover because European criminal justice systems mostly offer early release after half or a third of the sentence has been served.[12] In Rutaganira, for example, the Prosecution agreed to recommend that the sentence should be served in Europe or Swaziland (rather than in Mali where most ICTR convicts serve).[13]

Once the defendant has admitted his or her guilt no trial is needed[14] and the procedure moves on to the sentencing stage. Plea bargaining in some form or other[15] has developed in the United States in the $19^{\text {th }}$ Century[16] and then rapidly spread to many other criminal justice systems including civil law countries such as Germany, France and Italy.[17] It has now been used even in international criminal law.[18] In domestic criminal law it is often claimed that a modern criminal justice system would collapse if it were not for the fact that the majority of trials are replaced by informal negotiations.[19] However, while supporters praise the efficiency of this practice that frees up so many resources, opponents warn that defendants lose the procedural safeguards of a trial (most of all the presumption of innocence), that victims are not heard, that the public is excluded and that convicted criminals receive too lenient sentences.

This paper discusses whether the practice of plea bargaining might threaten the courts' ability to establish an accurate and accessible historical record and thus might undermine one of its most important functions. It will focus on the two international tribunals, the ICTY and the ICTR. The 
ICTY has been chosen as a case study of how plea bargaining has been introduced to international law and has developed over the years. The ICTR on the other hand, is one of the very few examples where the Tribunal and the Prosecution have not succeeded in establishing plea bargaining as wide used practice. After having examined the development and problems at the two ad hoc tribunals this paper concludes by making a number of proposals for the use of plea bargaining in the International Criminal Court (ICC).

\section{The Trial as Fact Finding Tool}

"We must establish incredible events by credible evidence.”[20]

The close link between historical truth, reconciliation and peace mentioned above is the reason why so many transitional societies have established Truth and Reconciliation Commissions.[21] International criminal trials, too, play a decisive role in establishing an accurate and publicly accessible historical record. Yet one has to examine closely what contribution a criminal trial can make. Neither judges nor prosecutors nor defence counsels are normally trained in historical research and only rarely are historians invited to give expert testimony.[22] In addition to this there are three aspects of a criminal trial which potentially hinder the courts' capacity to create a useful historical record.

First of all, most ad hoc tribunals have only a limited temporal and/or territorial jurisdiction[23] which often does not cover the whole conflict. For example, the ICTR has jurisdiction only over the events of the year 1994[24] not including the crimes before or after this time. Further, like municipal courts, international courts have to work with very limited resources and have to confine themselves to a minority of many possible cases. Accordingly they usually concentrate on those most responsible for the most serious crimes, such as political or military leaders, while a great number of perpetrators are not even investigated.[25] And even in the few remaining cases the Prosecution very often does not charge all possible offences but focuses on certain events at a certain location (maybe one concentration camp) or of a certain date (maybe the date of one massacre).[26] Consequently, in total only a small minority of crimes committed in a conflict will be brought to justice and made part of the historical record of the court. Nevertheless, concentrating on the most responsible offenders and uncovering their contribution and responsibility will add valuable information to the history of the whole conflict.

Secondly, only individuals are put on trial[27] and all evidence has to be related to the relevant charges against this individual defendant rather than the general historic background. Many argue therefore that truth commissions are in a better position to paint a comprehensive picture of the broader context of the violence.[28] Having said this one must not forget that many of the offences require the Prosecution to prove elements which comprise the general background such as the presence of an international or non-international armed conflict[29] a widespread or 
systematic attack directed against any civilian population [30] or intent to destroy part of a group.[31] Thus the fact finding of an individual case might very well include evidence of the larger context of the conflict including the operation of the regime and general policies, cooperation between different agencies, the role of the media, the involvement of army and police etc.

Finally, fact finding in court is limited by very strict evidential rules which might declare evidence inadmissible even if it is of vital value for the historical record.[32] However, the rules of evidence are generally much freer than in most adversarial systems. For example, the Rome Statute does not exclude hearsay evidence[33] which is often inadmissible in common law countries. The prime example of successful building of a historical record are the Nuremberg trials which in less than eleven months in only twenty-two cases exposed the Holocaust and the workings of the Nazi regime.[34] Today Germany under Nazi rule is one of the best researched times in history. The Prosecution in spite of being dependent on state co-operation has investigative powers which far exceed the possibilities of a historian, such as access to eye witnesses, expert witnesses and documents. Beyond and above establishing a historical record through trial does not only help to find out what happened but moreover it provides for a mechanism to validate these findings. The limits of evidential and procedural rules confer legitimacy and credibility to the outcome. An independent court establishes facts through a public trial where each element needs to be proven beyond reasonable doubt. Thus not only will the criminal investigation uncover the truth but the test of a criminal trial will also validate it. The thorough investigation of high profile offenders, the strict rules of evidence and the rule of law which allows both sides to be heard make the international criminal trial a most appropriate forum for building an accurate historical record of the atrocities.

\section{Does Plea Bargaining Hinder Building of a Historical Record?}

"The Trial Chamber finds that, on balance, guilty pleas pursuant to plea agreements, may further the work - and the mandate - of the Tribunal."[35]

Having established the importance of the historical record and the important contribution an international criminal trial can make it will now be examined to what extent the practice of plea bargaining supports or undermines this aim. After reviewing briefly the development of plea bargaining at the ICTY this section will examine the effects of plea bargaining on the building of a historical record, i.e. the avoidance of the full trial, the dropping of charges and the question of 
how to validate whether a guilty plea is genuine.

\section{Development in ICTY}

During the process of drafting the ICTY Statute[36] and its Rules of Evidence and Procedure (ICTY-RPE) the United States proposed to incorporate plea bargaining[37] but was unsuccessful.[38] When the question was raised again later, the tribunal made it quite clear that an international criminal tribunal was no place for plea bargaining.[39] Acknowledging some of the benefits of plea bargaining the then President Antonio Cassese declared that the crimes before this tribunal were too abhorrent to be part of a negotiation with the defendant.[40]

The situation changed dramatically, however, when the international community employed financial incentives to encourage the Balkan authorities to transfer indictees to the Tribunal and NATO agreed to arrest indictees.[41] Both developments meant that the caseload of the court was growing rapidly and that to hold full blown trials for each defendant became more and more difficult. The pressure increased further when the United Nations Security Council outlined a completion strategy in 2003 requiring bringing to a conclusion all trial activities at first instance by the end of 2008.[42] Aside from a few procedural amendments[43] one of the major strategies to cope with the case load was to begin to allow plea bargaining. A contributing factor was surely a change in ICTY presidency when Antonio Cassese was succeeded by Gabrielle Kirk McDonald from the United States, where the majority of criminal cases are dealt with through plea bargaining.[44]

Analysing the cases which the ICTY dealt with through plea agreements one can distinguish three phases.[45] In the first ten years only eight cases were disposed of involving plea agreements in the ICTY[46] and only two defendants received significant sentence concessions.[47] The first defendant at the ICTY to enter into a plea agreement with the Prosecution was Stevan Todorovi?.[48] One has to note however, that the agreement came about because of very special circumstances. Todorovi? claimed that he was unlawfully kidnapped and handed over to NATO forces in Bosnia-Herzegovina (SFOR). When he filed an interlocutory appeal challenging the legality of his arrest the ICTY Trial Chamber ordered SFOR and the participating states to provide Todorovi? with wide-ranging and potentially embarrassing information about the incident. Not surprisingly NATO, the United States and other states protested vehemently.[49] In November 2000, Defence and Prosecution filed a joint motion reflecting a plea agreement whereby Stevan Todorovi? would plead guilty to count one of the indictment.[50] Further, he would withdraw the interlocutory appeal and the allegations that his arrest was unlawful. He also agreed to co-operate with the Prosecution and to testify against other suspects. In exchange the Prosecution would formally request the withdrawal of counts two to twenty-seven of the indictment. In addition they agreed to recommend to the Trial Chamber a sentence range of between five years and twelve years[51] although the Prosecution expressed the belief that if found guilty at trial Todorovi? would have been sentenced to at least 15-25 years' imprisonment.[52] On 31 July 2001, he was sentenced to ten years' imprisonment which in the view of the Trial Chamber was a very significant sentence concession.[53] Although it is quite 
obvious that the core of the deal was the withdrawal of the potentially embarrassing interlocutory appeal the trial Chamber pointed out that "a guilty plea is always important for the purpose of establishing the truth in relation to a crime." [54] Notwithstanding the exceptional circumstances of this case Todorovi? paved the way for future sentencing bargains. The Trial Chamber declared for the first time that a guilty plea "should, in principle, give rise to a reduction in the sentence that the accused would otherwise have received".[55] Five months after this first case of sentencing bargaining the ICTY adopted Rule 62ter which provides for the procedure of approving plea agreements.[56]

A case which illustrates the court's growing preoccupation with how to deal with cases efficiently is Sikirica.[57] The three defendants (Du?ko Sikirica, Damir Dosen and Dragan Kolund?ija) were accused of not taking reasonable steps while they were in charge of the Keratem Camp to prevent the atrocities in the camp and even of having participated.[58] All three defendants were granted quite a low sentence although they entered their guilty plea long after the trial had started and the Prosecution had already closed their case and despite the fact that they did not agree to testify against other accused or to co-operate in any other way.[59] In its sentencing judgement the Court once again emphasised the mitigating effect of plea bargaining. Surprisingly, the decision to enter a guilty plea seems to have been given more value than the expression of remorse. "The Trial Chamber considers that the primary factor to be considered in mitigation of Du?ko Sikirica's sentence is his decision to enter a guilty plea, although it will also take into account his expression of remorse."[60]

Even more interesting is that the contribution to truth finding of a guilty plea appears to be secondary to saving time and effort for the Tribunal:

\begin{abstract}
A guilty plea facilitates the work of the International Tribunal in two ways. Firstly, by entering a plea of guilt before the commencement of his trial, an accused will save the International Tribunal the time and effort of a lengthy investigation and trial. Secondly, notwithstanding the timing of the guilty plea, a benefit accrues to the Trial Chamber, because a guilty plea contributes directly to one of the fundamental objectives of the International Tribunal: namely, its truth-finding function.[61]
\end{abstract}

In the second phase, during the years 2002 and 2003, one can observe a strong rise in the numbers of guilty pleas and generous sentence recommendations. However, at the same time the discomfort of the judiciary seems to be growing and increasingly the Trial Chambers refuse to follow the negotiated sentence recommendations. In the case of Dragan Nikoli? for example the judges disregarded the Prosecution's sentencing recommendation of fifteen years and sentenced the defendant to twenty-three years instead.[62] The Court declared that "the brutality, the number of crimes committed and the underlying intention to humiliate and degrade would render a sentence such as [the Prosecution] recommended unjust."[63] But the Court emphasised that the defendant still received some concession for his guilty plea without which he would have received 
a life sentence.[64] Reading this case closely it seems that the Court wanted to convey the impression that the fault for the disappointed expectation lay with the Prosecution who had offered an unrealistically high discount which the Chamber could not follow. At the same time the Chamber was anxious not to discourage future plea agreements and stressed that the defendant had still benefited considerably.[65] However, the number of cases where the Trial Chamber went beyond the Prosecution's recommendation increased. In the case of Momir Nikoli? the Prosecution offered to recommend a sentence of fifteen to twenty years' imprisonment. Instead the Trial Chamber sentenced him to twenty-seven years[66] explaining "the testimony of Momir Nikoli? was evasive and [...] an indication that his willingness to co-operate does not translate into being fully forthcoming in relation to all the events, given his position and knowledge".[67] Even in cases where the Court sentenced according to the agreement judges expressed their discomfort. In Deronji?[68] the presiding judge Wolfgang Schomburg dissented wholehearted with the sentence reduction based on an agreement and declared that justice would have required double of his ten years' prison sentence.[69] Reading Deronji?'s witness statement in the Krsti? Appeal hearing it becomes clear that the ICTY had information about more involvement of Deronjic than is reflected in his charges and sentence.

After 2003 a third phase began, in which the number of guilty pleas decreased[70] according to Combs for three reasons. First, victims' groups and legal commentators increasingly criticised the in their view much too lenient sentences and the avoidance of public trial.[71] Second Michael Johnson, the Chief of Prosecution who was a strong advocate of plea bargaining and who promoted many agreements left The Hague in 2003.[72] The third and probably most important reason for the drop in plea agreements however was that subsequent to the repeated rejections of the agreed sentence recommendation by the Court defendants lost the trust that the bargains would stand.[73]

Looking at the development of plea bargaining at the ICTY it becomes clear that initially this practice had been developed as a response to the growing case pressure. Although the ICTY noted in 2003[74] that plea bargaining has other justifications alongside efficiency initially it was clearly introduced as a measure to cope with an increasing caseload and insufficient resources. As Petrig observes: "The timing of its introduction, after the docket had grown considerably and the efficiency and completion discussion was launched supports this conclusion".[75] Scharf estimates that if "the ad hoc Tribunals had been given an additional five years to complete their mandate, then the need for plea-bargaining could have been avoided."'[76] In the remainder of this section it will be discussed whether this mechanism of efficiency can be used to enhance the historical record building function of international criminal procedures.

\section{Encouraging Guilty Pleas}

Plea bargaining offers one of the strongest incentives for defendants to enter a guilty plea. The 
fact that defendants (especially leading figures) admit their guilt without challenging the allegations at trial can have an important effect on the credibility of the historical record. Moreover, not challenging the allegations but admitting responsibility can also make a valuable contribution to reconciliation. In Nikoli? the Court underlined that the "recognition of the crimes committed against the Bosnian Muslim population in 1995 [...] by a participant in those crimes contributes to establishing a historical record."[77] The guilty plea of Plav?i? was praised by the Prosecution as "an unprecedented contribution to the establishment of truth and a significant effort toward the advancement of reconciliation".[78] Biljana Plav?i?, known as the 'Serbian Iron Lady' served under the Bosnian Serb leader Radovan Karadzic as deputy and later became President of the Republika Srpska. Even though she did not directly participate in the atrocities she provided important assistance by publicly promoting displacement and encouraging Serbian paramilitaries to participate in the 'ethnic cleansing'.[79] Although she repeatedly refused to testify against other suspects, Plav?i? acknowledged that the Bosnian Serb leadership had been responsible for the wide spread 'ethnic cleansing' [80] and that the Bosnian forces with support of Serbian paramilitary units and even Yugoslavia's army, implemented the "objective of ethnic separation by force".[81] No less than Madeleine Albright, then U.S. Secretary of State during the Clinton administration, and Dr Alex Boraine, Deputy Chairperson of the South African Truth and Reconciliation and founding President of the International Centre for Transitional Justice emphasised the contribution towards reconciliation in Bosnia Plav?i? made with her guilty plea. Dr Boraine praised "the acknowledgement and acceptance of responsibility for grave crimes, and the impact this can have on the process of reconciliation."'[82] He gave four reasons for the significance of Plav?i?'s plea of guilty:

firstly, as the plea of guilty was offered by a Serb nationalist and former political leader, Mrs. Plav?i?'s confession sends out a crucial message about the true criminal nature of the enterprise in which she was involved; secondly, by surrendering and pleading guilty, Mrs. Plav?i? is also sending a powerful message about the legitimacy of the International Tribunal and its functions; thirdly, Mrs. Plav?i?'s apology for her actions and her call on other leaders to examine their own conduct is of particular importance; and fourthly, the confession of guilt and acceptance of responsibility by Mrs. Plav?i? may demonstrate to the victims of the persecutory campaign that someone has acknowledged their personal suffering.[83]

Unlike Todorovi?, Plav?i? refused repeatedly to co-operate with the court beyond her guilty plea, in particular to testify against Slobodan Milosevi?. Nevertheless the Trial Chamber held that the mitigation effect of the guilty plea outweighed the gravity of the crime, because she admitted responsibility for the deaths of tens of thousands of civilians. Plav?i? was sentenced to eleven years imprisonment with the possibility of early release for good behaviour[84] on grounds of four mitigating circumstances: her voluntary surrender, her age, her post-conflict conduct (actively supporting and being instrumental in the implementation of the Dayton Peace Agreement by taking political and personal risks) and her guilty plea.[85]

It is hoped that if the leaders admit their guilt their followers will accept the truth about the atrocities and accept the injustice done to the victims. Confessions of important leaders will 
diminish the risk that former crimes are denied or justified. Thus an admission of guilt, encouraged by plea bargaining might contribute more to reconciliation than the conviction of a defendant who is claiming his innocence or tries to justify the atrocities committed. On the other hand an admission which is submitted alone for tactical reasons will have the opposite effect. As soon as Plav?i? received early release after having served two thirds of her 11-year sentence she retracted her confession and declared "I sacrificed myself. I have done nothing wrong. I pleaded guilty to crimes against humanity so I could bargain for the other charges. If I hadn't, the trial would have lasted three, three and-a-half years. Considering my age that wasn't an option.'[86]

This proof of lack of genuine remorse is confirmed by the fact that with the exception of her testimony against Momcilo Kraji?nik, Plav?i? has consistently refused any cooperation with the Tribunal. Her case proves that although plea bargaining can encourage admissions of guilt, which serve the historical record and reconciliation, it can also undermine both aims if the incentive of the bargain is so strong that it triggers non insincere admissions. In addition to this there are a number of aspects, which mean that plea bargaining can undermine the building of a historical record.

\section{Loss of Trial}

The first problem is that plea bargaining bypasses the fact finding trial which has the potential of making a very significant contribution to the historical record as was shown above. Rather than having a huge volume of evidence examined and being able to paint a detailed picture of what has happened, the defendant agrees simply to the Prosecution's summary of facts. Biljana Plav?i? when pleading guilty did not reveal any new facts[87] but merely confirmed the statement the Prosecutor has submitted in a short five-page document.[88] In comparison, a judgement of the ICTY tends to comprise several hundreds of pages,[89] and trial transcripts run into tens of thousands of pages in addition to witness statements, official documents and other evidence.[90]

Furthermore, in case of a guilty plea the facts stated by the Prosecution and admitted by the Defence are not tested in trial under strict evidentiary rules and thus might not have credibility for the public. Taking again the example of Plav?i?, rather than accepting the new truth about the Serbian leadership, many Serbs disregarded the admission of guilt as treachery of Plav?i? who in their eyes only agreed to these facts for her own personal benefits.[91]

Moreover the acceptance of a guilty plea bears the risk that important legal questions are not contested and discussed at trial. In the case of Erdemovi?, for example, the guilty plea avoided a full discussion of the question of duress at trial. In the sentencing judgement the Trial Chamber came to the conclusion that on"the basis of the case-by-case approach and in light of all the elements before it, the Trial Chamber is of the view that proof of the specific circumstances which would fully exonerate the accused of his responsibility has not been provided.'[92] This question should have been discussed in court where Erdemovi? would have had the opportunity to present such evidence or even challenge the burden of proof in the first place.[93] 


\section{Charge Bargaining}

The main problem regarding the aim of painting a comprehensive historical picture, however, is the practice of charge bargaining, in which the prosecution withdraws charges in exchange for a guilty plea to the remaining charges. Not only does the defendant not need to admit or reject responsibility for the withdrawn crimes but moreover the facts underlying these charges are not read into the court records at all. All evidence collected for these charges by the Prosecution, including reliable eye witness statements, are lost for the general historical record. Even worse, when charges are dropped it is not recorded whether this is part of an agreement or because of lack of sufficient evidence on the part of the Prosecution.[94] This means that the dropping of charges can be interpreted as if those crimes have not happened at all.[95]

In Plav?i? of the two counts of committing genocide and complicity in genocide and six counts of committing crimes against humanity all except one charge of persecution were dropped.[96] Another case where the plea agreement resulted in avoiding a trial which should have taken place is Simi?,[97] which demonstrates very clearly how much importance is given to efficiency considerations. Blagoje Simi? surrendered voluntarily to the ICTY and pleaded not guilty to all counts. Eight months after the trial began, on 15 May 2002, he pleaded guilty to two counts of torture as a crime against humanity in exchange for a low sentence recommendation (not more than five years' imprisonment) and the dropping of all other counts. A bargain was offered to the defendant although the Prosecution felt that they had good evidence and thus good chances of a conviction because they considered that the ill health of the defendant would probably prolong the trial considerably.[98] Considering the seriousness of all the charges that were dropped notwithstanding a good chance of finding Simi? guilty of each of them the low sentence cannot be justified by the savings in resources made. In Nikoli? the ICTY pointed out that the sentence must mirror the responsibility of the defendant and "reflect the actual conduct and crime committed and must not simply reflect the agreement of the parties as to what would be a suitable settlement of the matter.'[99]

One of the most serious problems with charge bargaining is the distortion of the historical record when too many charges of the same offence are dropped. The repeated withdrawing of genocide charges in favour of crimes against humanity could mean that it might never be established that genocide has actually taken place.[100] For groups who deny the true nature of the atrocities it will be very easy to declare that the Prosecution never has proven genocide has happened in a particular conflict whereas in reality the Prosecution had never taken the opportunity to do so. Another example is sexual violence which forms part of every armed conflict. A prosecutor of the ICTY explained[101] that many defendants refuse to admit sexual offences even where they are willing to admit other acts of violence. This means that many deals are made which result in withdrawing charges of sexual violence. As a result a huge number of sexual offences are not made part of the historical record established by the courts. The ICTR has been proven to be very progressive in developing jurisdiction in sexual crimes and making this 
horrible but typical side of armed conflicts visible. But charge bargaining could lead to the result that the systematic victimisation of women and use of sexual violence as a weapon is disappearing again from the public record. In addition, this experience could influence prosecution policies and practices in the long run, as it might be decided that thorough investigation in sexual crimes is not the best use of resources if these crimes are very likely to be bargained away later.

However if the historical facts of a certain situation have been already established in an earlier case and the present case would not offer much new information the value of an additional trial in this respect is questionable. In such a case a brief admission of guilt to facts already established does not hinder the historical record effect of the court procedures in total.

\section{Is the Guilty Plea Genuine?}

Plea bargaining can only support the establishment of a historical record if it produces guilty pleas which are genuine. A plea which is based on threats or an uninformed decision not only fails to establish an accurate historical record in this particular case but also it undermines the legitimacy of the whole truth-finding process of the court. Unfortunately the experience of the ICTY has shown that judges are not very diligent in investigating the validity of a guilty plea. An analysis of the problems in this tribunal will lead on to proposals for future use of the practice, especially at the ICC.

\section{Development of Procedural Safeguard for Guilty Pleas}

The first case in which the question of the validity of the guilty plea was raised was Erdemovi?. Dra?en Erdemovi? was accused of having participated in the massacre of hundreds of Bosnian Muslims civilians near Pilica.[102] He was indicted on one count of a crime against humanity and an alternative count of a violation of the laws or customs of war.[103] The tribunal dismissed the charge of violation of laws or customs of war and accepted the guilty plea for the count on crimes against humanity.[104] Handing down its very first sentence decision the ICTY sentenced Erdemovi? to ten years' imprisonment.[105] This case was not the result of a plea agreement but is essential for the question of the necessary requirements of accepting a guilty plea.[106] When Erdemovi? appealed against his sentence arguing that his defence of duress had not been considered sufficiently, the Appeal Chamber took the opportunity to question the validity of the appellant's guilty plea as well.[107] Being the first international criminal tribunal that introduced the common law procedure of guilty plea[108] the Appeal Chamber was eager to clarify its procedure. It noted the benefits of accepting a guilty plea and thus avoiding a full-blown trial.[109]

This common law institution of the guilty plea should, in our view, find a ready place in an international criminal forum such as the International Tribunal confronted by cases which, by their inherent nature, are very complex and necessarily require lengthy hearings if they go to trial under stringent financial constraints arising from allocations made by the United Nations itself dependent upon the contributions of States.[110] 
However, it made it clear that the defendant's waiver of his or her right to trial with its wide catalogue of defendants' rights[111] can only be allowed if the procedure of accepting the plea offers some safeguards itself. [112] Leaning on the experience of common law systems and in particular Rule 11 of the Federal Rules of Criminal Procedure, the Appeal Chamber set out and defined three requirements for accepting a guilty plea. The plea must be entered voluntarily, knowingly, and unequivocally. 'Voluntary' means not only that the defendant pleaded guilty without threats, inducements or promises[113] but also that they would understand the consequences of the plea.[114] A plea is 'knowing' if the defendant knows and understands the charges against them and all the elements that the Prosecution need to prove. Moreover the defendant needs to comprehend the rights which are given up by waiving the right to a fair trial and the penal consequences. Thirdly, the plea must not be ambiguous or equivocal.[115]

The Trial Chamber's acceptance of the guilty plea in Erdemovi? was problematic for three reasons. Firstly, the Appeal Chamber was not convinced that the defendant had been aware of the rights and safeguards he was giving up by waiving his right to a fair trial, in particular the presumption of innocence.[116] Secondly, it seems that the defendant did not understand the charges he was pleading guilty to. At his initial appearance he had been confronted with two alternative charges and been asked simply whether to plead guilty or not guilty without distinguishing between the two crimes.[117] He did not receive an explanation and very probably did not understand the differences between the two alternative charges.[118] He first simply pleaded guilty without specifying to which count[119] and then to the more serious crime[120] which suggests that he did not grasp the differences between the two offences. Thirdly, while pleading guilty he kept emphasising that he had acted under the threat of being killed himself.[121] This suggests that he admitted parts of the offence but did not hold himself guilty as he believed he had a legal defence.[122] A plea which indicates that on the one hand the charges are admitted but at the same time deny responsibility is inherently contradictory and ambiguous and must not be accepted.[123]Although his counsel was present at the time of the plea the defendant understood neither the nature of the offences he was charged with nor possible defences. The Appeal Chamber ordered that Erdemovi? be given the opportunity to plead again and he pleaded guilty before the Trial Chamber IIter to murder as a violation of the laws or customs of war and was sentenced to five years.[124]

Only a month after the appeal decision the judges of the ICTY adopted at the Fourteenth Plenary Session on 12 November 1997 Rule 62bis of the Rules of Procedure and Evidence.[125] Following the Appeal Chamber, Rule 62bis requires that the guilty plea is entered knowingly, voluntarily, and unequivocally, and that there is a factual basis to support the plea. However, surprisingly the new rule does not incorporate the detailed requirements of Rule 11 nor the detailed ruling of the Appeal Chamber. Neither does it offer definitions of these principles nor does it give any guidelines on how the Trial Chamber is expected to find that the plea meets the requirements.

\section{Implementation of Procedural Safeguard for Guilty Pleas}


According to Cook this vagueness of the new procedure led to a "hodgepodge judicial approach to Rule 62bis".[126] A look at the transcripts of the Trial Chamber hearings when accepting a guilty plea reveals that even the rudimentary requirements of Rule 62bis were fulfilled only formally by the court.

THE ACCUSED PLAV?I?: [Interpretation] I plead guilty.

JUDGE MAY: You plead guilty. The Rules of the Tribunal require that the Trial Chamber is satisfied that a plea of guilty has been made voluntarily, that it is informed and not equivocal, and that there is a sufficient factual basis for the crime and the participation of the accused in it. Mrs. Plav?i?, in the plea agreement which we have read, you have signed a declaration that you entered into the agreement freely and voluntarily, understanding its terms, and having been advised by your lawyers. You have also signed a statement to the same effect in which is added that the plea is informed and unequivocal. Do you confirm that those declarations are correct?

\section{THE ACCUSED PLAV??: [Interpretation] I do.[127]}

Although Judge May checked formally whether the requirements of Rule 62bis were satisfied he did not ask about any of the elements. If Rule $62 \mathrm{bis}$ is to be taken seriously it is necessary to examine carefully whether each of the requirements is met, for example whether the defendant understands each element of the offence that the Prosecution need to prove or the extent of the rights the defendant is going to lose when giving up the right to trial. The Chamber did nothing to convince itself that the defendant understood either the rights she gave up or the consequences of her decision. The Court obviously treated this part of the procedure as a mere formality trusting that the lawyers had done their job of informing the defendant adequately. However, the duty to protect the defendant against abuse of procedure lies according to Rule 62bis with the court and cannot be delegated to the defence counsel.

Another example is the case of Ranko ?e?i? who pleaded guilty to all of the six counts of crimes against humanity and six violations of the laws or customs of war[128] and was sentenced to eighteen years imprisonment.[129] When accepting the guilty plea the judge asked the defendant only whether he understood that the court was not bound by the sentencing recommendations of the Prosecution and whether he entered the agreement voluntarily and not due to threats or undue force. There was no reference to the other requirements of Rule 62bis[130] and neither the fact that he was giving up the presumption of innocence, nor the elements of the offences that the Prosecution need to prove nor the maximum possible sentence were mentioned to the defendant.[131] The court declared that the requirements were fulfilled but ?e?i? was not asked about them.[132] Except for changing his plea from not guilty to guilty[133] and then pleading guilty to each of the counts the accused only spoke three times at the hearing himself: he confirmed that it was his signature on the agreement[134], he confirmed that he understood that 
the Trial Chamber is not bound by recommendation,[135] and he confirmed that he had entered the agreement voluntarily.[136] Defence counsel declared that the accused understood all aspects of the plea agreement[137] but the Chamber did not endeavour to convince itself that the defendant himself had the necessary understanding.

Both cases show that the judges are aware of the safeguards of the procedural rules against abuse of plea bargaining but do not really implement them. Rule 62bis is mentioned, or at least some of the requirements are referred to, but none of the elements are examined in any detail. If the guilty plea is based on one of the situations which Rule 62bis is designed to prevent (for example the defendant was threatened) the defendant will give all the answers they think are expected from them. A formalaic approach to Rule 62bis will thus not be able to identify such situations.

A related problem is that some Chambers use a shortcut to Rule 62bis by asking the defendant to confirm the fulfilment of all elements in one single compound question. An example is the case of $M r$ ?a.[138] The defendant was charged with two counts of crimes against humanity and one count of violations of the laws or customs of war. After entering a plea agreement with the Prosecution Mr?a changed his plea of not guilty at his initial appearance to a guilty plea to counts two and three.[139] After the Court summarised the plea agreement in total the accused was simply asked whether he understood the documents. [140] With his brief reply "Your Honour, everything is clear to me" the Court seems to have satisfied itself that all requirements of Rule 62 bis had been fulfilled. The judge mentioned some of the rights he would give up[141] but the list is far from complete and the presumption of innocence and the prosecutor's burden of proof were missing. In the case of Babi?[142] the court considered each of the factors of Rules 62 bis and read the entire plea agreement into the record.[143] When after the reading the whole document of fifteen pages, the court asked the defendant whether he was aware of the consequences of entering a guilty plea, Babi? answered simply: "Your Honour, I am aware".[144] This general information was deemed to be sufficient that the defendant was appropriately safeguarded. Although this case is an improvement because it at least listed all the criteria of Rule 62 bis the fact that the defendant was asked to confirm all elements together is questionable. The court should convince itself that each of the elements are understood and confirmed by the defendant.

Since the Court is not bound by the agreement between Prosecution and Defence the defendant cannot risk to do anything that would cast a doubt on their genuine remorse and provoke the court to disregard the sentence recommendation of the Prosecution. Cook makes clear that under these circumstances the defendant has hardly a chance to take advantage of Rule 62bis. "With a defendant fully inclined to appear cooperative and deferential, and fully disinclined to appear inquisitorial or confrontational, the court's cursory examination of Babic hardly suffices as a legitimate barometer of the defendant's acumen regarding the plea decision."[145]

By taking together all questions of Rule 62bis into one compound question the court is supporting this assumption rather than really attempting to find out whether all the conditions of Rule 62bis are met and the defendant really entered the plea voluntarily and informed. A 
compound question considering more than one element of Rule 62bis should therefore be prohibited.

\section{Developing a Strategy}

"The prospect of spending the rest of his life behind bars was, his counsel believes, of less concern to his defendant than was his opportunity to create through his trial a historical record that might, even many years from now, vindicate his view of the conflict."'[146]

An interesting turn in the question of the relationship between plea bargaining and the historical record is the experience of the ICTR. Combs found in her empirical research that the sentence discount seems to be the major incentive for defendants at the ICTY but does not seem to play a major role in the ICTR[147] and indeed the number of plea agreements is here much lower.[148]

The national criminal justice system of Rwanda is based on the French and Belgium systems which are civil law countries with inquisitorial systems and like Yugoslavia and the successor states, Rwanda does not engage in plea bargaining. Nevertheless, like the ICTY the ICTR also amended its Rules of Procedure and Evidence (ICTR-RPE)[149] to provide for the guilty plea procedure.[150] What is most striking when looking at the guilty pleas of the ICTR is that while plea bargaining seems to spread over the whole world this court does not manage to establish a culture of guilty pleas. This is true despite the fact that the court itself spent some efforts to do so.

The arguably most important case of the ICTR is the case against the former Prime Minister Jean-Paul Kambanda. At his initial appearance on 1 May 1998 he pleaded guilty to all charges, i.e. one count of genocide, one count of conspiracy to commit genocide, one count of direct and public incitement to commit genocide, one count of complicity in genocide, and one count of crimes against humanity (murder), and one count of crimes against humanity (extermination).[151] In addition he offered right from the beginning to co-operate with the Prosecution and promised to testify for the Prosecution in those trials.[152] He provided ninety hours of recorded evidence which was "invaluable information" [153] that was later used against other leaders. This co-operation was based on a written plea agreement between Kambanda and the Prosecution which explicitly "records that no agreements, understandings or promises have been made between the parties with respect to sentence which, it is acknowledged, is at the discretion of the Trial Chamber.'[154] Nevertheless for his early plea and extensive co-operation Kambanda had expected a huge sentence discount, an expectation which must have been shared by his counsel who argued for only two years' imprisonment.[155] In spite of his confession and full co-operation the Court refused however to give any sentence concession, and following the Prosecution's recommendation it sentenced Kambanda to life imprisonment.[156] Although it 
acknowledged the advantages of a guilty plea the Court made it clear that the plea could not outweigh the aggravating circumstances.[157] The denial of a sentence reduction is surprising: Kambanda had pleaded guilty before any other trial at the ICTR was completed.[158] Thus the Tribunal had here the opportunity to send a powerful message to other accused and encourage them to plead guilty. Secondly, given the early plea and the extent of co-operation the Trial Chamber could easily have justified a more lenient sentence.[159] Further, one of the aggravating factors, Kambanda's political position could actually have been counted as mitigation.[160] Although the Trial Chamber in Plav?i? agreed with the Prosecution[161] that Biljana Plav?i?'s former position as President of the Republika Srpska was an aggravating factor it pointed out that an admission of guilt of a political leader has special value for reconciliation.[162] Hearing his sentence Kambanda immediately stopped co-operation with the Prosecution and filed an appeal[163] claiming among other things that the Trial Chamber had not considered his guilty plea as a mitigating factor to discount his sentence.[164] The Appeal Chamber unanimously rejected the appeal and confirmed the sentence.[165]

In this case the defendant had already provided a huge amount of invaluable information to the Prosecution, which not only helped other prosecutions and convictions but also contributed to the historical record. In this regard the Prosecution did not need to offer a lenient sentence recommendation. However, the disappointment of the defendant who felt betrayed in his agreement had a long term effect on other defendants and contributed to the general reluctance to enter into plea agreements.[166] This case shows that if a court decides to develop the practice of plea agreement it has to establish some long-term strategy. Plea bargaining is a practice which cannot be used only in isolated cases.

The ICTR seemed to try to undo the damage in Serushago.[167] Omar Serushago surrendered to the ICTR in April 1997 although he was not indicted by the court,[168] and pleaded guilty at his initial appearance on 14 December 1998.[169] He provided full co-operation before and after his trial and submitted information against many other high-level defendants. Serushago was the first case in which the Prosecution recommended a sentence below life imprisonment.[170] Emphasising the defendant's extensive co-operation they recommended a twenty-five years' prison sentence. [171] The Trial Chamber acknowledged the mitigating effect of the guilty plea and other mitigating circumstances such as his co-operation with the Prosecution, his character, his regret and remorse, and his assistance to victims.[172] Surprisingly, the Trial Chamber went even below the Prosecution's recommendation and sentenced him to only fifteen years.[173] However, neither the low sentence in Serushago nor the explicit promises by both the Court and the Prosecution of significant sentence concessions for guilty pleas achieved a considerable rise in guilty pleas as the ICTY experienced in 2002 and 2003. Indeed the ICTR had to wait for over four years for the next guilty plea.

Vincent Rutaganira who was the fourth guilty plea at the ICTR pleaded guilty in December 2004.[174] Six years after the Prosecution had issued an indictment against Rutaganira in 1996 he surrendered voluntarily in February 2002. After he pleaded guilty to one count of aiding and 
abetting exterminations as a crime against humanity the Prosecution not only dropped the other five counts but even asked the Trial Chamber to acquit him on these counts because of lack of sufficient evidence.[175] Further the Prosecution recommended a very low sentence of between six and eight years and that this sentence should be served in Europe or Swaziland.[176] It was also explicitly stated in the plea agreement that there would not be any further co-operation with the Prosecution.[177] The Trial Chamber sentenced him to six years and acquitted him from the other charges.[178] Rutaganira was the first case before the ICTR of explicit sentence bargaining as for the first time the Prosecution committed itself to a specific sentence recommendation range. It is also the first case of charge bargaining.[179] Combs argues that the reason for the Prosecution to give so many concessions for so little admissions by the defendant was a lack of sufficient evidence for the charges Rutaganira did not plead guilty to.[180] However in my view it is fair to conclude that since Serushago did not have the hoped effect of encouraging guilty pleas the Prosecution started to make better offers to defendants. Most of all the Prosecution began to offer the security of, if not a binding sentence promise, at least a binding sentence recommendation.

In Ruggiu the ICTR tried to stimulate guilty pleas by using the opportunity to praising the guilty plea because it "facilitates the administration of justice by expediting proceedings and saving resources ( ... ) [saving] the Tribunal a lengthy investigation and trial, thus economising time, effort and resources."[181] Citing Erdemovi? the court pointed out that rewarding guilty pleas with sentence concessions encourages other suspects to come forward.[182] Indeed the Trial Chamber explicitly targeted other suspects and perpetrators promising some form of concession.[183] When the Prosecution was criticised for the low sentence by the Rwandan government Chief of Prosecutions Mohamed Othman explained that it was "a good gesture for other accused who would wish to plead guilty and accept responsibility for their crimes."[184]

Although the Court and the Prosecution tried now to engage in plea negotiations in many cases[185] one still finds surprisingly few guilty pleas at the ICTR. The findings of Comb's research came to the surprising conclusion that the reasons why most defendants at the ICTR refuse to plead guilty is that they truly believe they are not guilty of the crimes they are charged with.[186] They argue that it was an armed conflict between the Rwandan government and the RPF (Rwandan Patriotic Front) and criticise that no member of the RPF was prosecuted. More importantly, most defendants reject the notion that the atrocities of 1994 in Rwanda can be classified as genocide.[187] While they agree that the conflict resulted in excessive violence they insist there was no genocidal intent against the Tutsi. [188] However, the reasons are different for high-level and low-level offenders:

High-level ICTR defendants, for instance, are so convinced of their innocence, so ideologically committed to their characterization of the Rwandan conflict, and so concerned about their place in the history books that virtually no sentence inducement will persuade them to plead guilty to genocide. Low-level Special Panels defendants, by contrast, are so ignorant about their legal rights and so culturally disposed to admitting wrongdoing and seeking reconciliation that, absent the constraining hand of counsel, no sentence inducement 
is needed to persuade them to plead guilty.[189]

Combs argue that one reason for the reluctance of guilty pleas at the ICTR is that the defendants are mostly "senior politicians, military leaders, or influential business people" and thus are highly concerned with the characterisation of the conflict and their own "historical legacy".[190] The label of the offence as well as the historical picture painted by the tribunal is essential for these defendants. Combs argues that defendants are willing to admit the violence they are responsible for but "cannot admit to taking part in a genocide because doing so would be fundamentally at odds with the defendant community's long-held characterisation of the violence.”[191]

These findings support my argument that plea bargaining can distort the historical record even though in the case of the ICTR it is the defendants who reject the idea of a bargain which distorts history as it has happened in their view.

\section{Conclusions}

“This 'historical' dimension of international criminal trials, which has some merits, complicates matters even further and often leads the proceedings far beyond their purpose of being instrumental to the ascertainment of specific individual responsibilities."[192]

It has been shown that the establishment of a historical record is a fundamental function of international criminal trials. Plea bargaining is an ambiguous tool that can both further and hinder this aim. Charge bargaining can distort the historical record while inauthentic pleas destroy the legitimacy of the court. One the other hand plea bargaining is the strongest incentive for perpetrators to admit their guilt and reveal the truth and thus support peace and reconciliation. Referring to the ICTY it was claimed that "confessions required for a deal are finally helping the tribunal to fulfil one of its central missions: persuading Balkan nations accustomed to considering themselves victims that their forces committed terrible crimes."[193]

The question of how to use plea bargaining in a way that advances rather than obstruct the historical record is essential because plea bargaining is expected to be used in all international and hybrid courts.[194] In particular the ICC has to take advantage of being able to draw conclusions from the experience of other international courts and to design procedures to reap the benefits of plea bargaining while avoiding the disadvantages of this practice. As was shown above a regulation of plea agreements in the Rules of Procedures alone does not guarantee that plea bargaining is used only in appropriate situations. Rather Court and Prosecution need to be aware 
of the far reaching consequences of a plea agreement and develop an adequate practice taking the different interests into consideration. The ICC[195] must not wait until an overwhelming caseload forces the courtroom actors to develop informally a practice of plea bargaining based on considerations of efficiency. Instead the Court should reflect now on the advantages and dangers of plea bargaining and design a procedure that safeguards not only the interest of defendants, victims and the international community but also the legitimacy of the Court itself. Plea bargaining must not be regarded as a convenient informal shortcut to avoid trials but can be utilised as a mechanism to build the historical record.

Three aspects emerged from the analysis of ICTY cases that are crucial: first, the disposal of full trials should be used only rarely because a criminal trial is one of the most effective ways to establish an accurate historical record. Only when facts are already established in earlier cases can it be justified to replace the trial with an agreement.

Secondly, the question of whether to facilitate plea negotiations with an accused should not be seen in isolation of the individual case but in the context of the whole situation. It must be kept in mind that the result of extensive plea bargaining might lead to a distorted picture painted by the Court. The Prosecution has to make sure that plea bargaining does not lead to a particular kind of crime, for example sexual violence, disappearing from the public record. Especially in cases where the outcome of a legal evaluation is uncertain[196] the Prosecution must avoid the temptation of turning away from the challenge of the trial. Instead the Court must have the opportunity to clarify this question in public with all sides presenting their arguments and evidence. The question of which cases are appropriate for plea bargaining needs to be made part of the Prosecutional strategy and policies including explicit selection criteria.

Thirdly, it has to be remembered that the historical record of a criminal trial can only claim legitimacy if it is established by the strict rules of procedure. Only if the guilty plea is genuine can the Court afford to neglect its mandate and dispose of the case without full trial. In order to maintain legitimacy and credibility, the Court has to take the safeguards seriously and examine each guilty plea, especially when based on a plea agreement. The rules set out by the Appeal Chamber in Erdemovi? offer appropriate protection and even in its curtailed form of Rule 62 bis provide for valuable safeguards for the defendant. Article 65(1) Rome Statute[197] is based on Rule 62bis. However, the experience of the ICTY has shown that the central question is to what extent the Court is really examining each of the elements seriously. Of course the Court has only limited possibilities to ascertain the understanding of a defendant or inspect whether there has been any undue pressure if the defendant claims there has not been any. However, the Court could ask why the defendant changed their non guilty plea to a guilty plea and enquire the conditions under which the plea agreement was made.[198] Moreover, the Court can take the time to explain the different charges, the consequences of entering a guilty plea, most of all the rights which the defendant is giving up by waiving their right to trial. Germany for example has introduced a new provision in its Criminal Procedure Code that requires the Court (and not counsel) to inform the defendant about the requirements and the consequences of an admission of guilt based on an agreement.[199] I propose that this duty of information should also be laid on the ICC. Based on the experience of Erdemovi? the Court could also enquire if the defendant 
claims any form of defence. [200]

To summarise I argue that international criminal courts and tribunals[201] should use plea bargaining to establish not only the guilt of offenders but also to further the historical record if the following three conditions are met:

1) Fact finding through trial

The broader picture of a certain situation, be it the legal classification of an atrocity (for example as genocide) or the fact of a certain crime (for example a certain massacre) or the pattern of certain crimes (for example use of sexual violence as a systematic weapon) or the wider context (for example widespread attack on civilian population) is already established through other cases so that a trial of the present defendant would not add significantly to these findings.

2) No distortion of history

Charge bargaining is only used in the context of the broader picture of all cases and as part of the prosecutorial strategy that ensures that no aspect of the conflict such as a certain type of crime disappears from the historical record.

3) Validity of the Plea

The court examines carefully whether the plea is genuine, i.e. whether it has been entered voluntarily, informed and unequivocally and is based on established facts.

These three conditions mean that the Court needs to keep the broader picture of the whole situation and not just the individual case in mind. Also they need to spend more time and effort on examining the validity of the plea. Of course this means the admission of guilt hearing[202] will take longer. However, considering the resources saved through avoiding a whole trial and considering the importance of the guilty plea this investment in examining the validity of the plea is worth the extra effort. Applying the safeguards listed above plea bargaining can be used without losing legitimacy of the procedure and without compromising the Court's function of building a historical record. As Hans-Peter Marsch reminds us: "the procedure gives legitimacy to the result".[203]

[1] Prosecutor v. Deronji |[pic] (Case No. IT-02-61-S) Dissenting Opinion of Judge Schomburg (30 March 2004) para. 6.

[2] U.S. Representative Mrs Albrigh Deronji? (Case No. IT-02-61-S) Dissenting Opinion of Judge Schomburg (30 March 2004) para. 6.

[3] U.S. Representative Mrs Albright statement 25 May 1993 UN SCOR, 48 ${ }^{\text {th }}$ session, 3217 th meeting UN 
Doc. S/PV3217.

[4] International Tribunal for the Prosecution of Persons Responsible for Serious Violations of International Humanitarian Law Committed in the Territory of the Former Yugoslavia since 1991, short International Criminal Tribunal for the former Yugoslavia (ICTY) established by UN SC Res 827, 25 May 1993.

[5] The International Criminal Tribunal for Rwanda (ICTR) established through UN SC Res 955, 8 November 1994.

[6] Michael P. Scharf 'The Politics of Establishing an International Criminal Court' 6 Duke Journal of Comparative and International Law (1995) 167, p. 168.

[7] Nancy Armoury Combs 'Prosecutor v. Plav?i?, Case No. IT-00-39\&40/ 1-S. Sentencing Judgment' 97 American Journal for International Law (2003) 929, p. 931.

[8] Michael P. Scharf ‘Trading Justice for Efficiency' 2 Journal of International Criminal Justice (2004) 1070, p. 1079.

[9] George William Mugwanya 'Expunging The Ghost of Impunity for Severe and Gross Violations of Human Rights and the Commission of Delicti Jus Gentium: A Case for the Domestication of International Criminal Law and the Establishment of a Strong Permanent International Criminal Court' 8 Michigan State University-DCL Journal of International Law (1999) 701, p. 765.

[10] Prosecutor v. Momir Nikoli? (Case No. IT-02-60/1-S) Sentencing Judgment (2 December 2003) para. 60.

[11] Combs supra note 6, p. 933.

[12] For example a charge of rape could be downgraded to a charge of sexual assault, or murder to manslaughter.

[13] Nancy Armoury Combs 'Procuring Guilty Pleas for International Crimes: The Limited Influence of Sentence Discounts' (59/1) Vanderbilt Law Review (2006) 69, p. 114.

[14] Prosecutor v. Rutaganira (Case No. ICTR-95-1C-T) Minutes of Proceedings (17 January 2005) para. 1(c).

[15] Or as the case is in most civil law countries the trial is very much shortened.

[16] Since many civil law countries do not have the procedure of pleading it is strictly speaking incorrect to speak of plea bargaining but this general term has now been established in the literature to include informal agreements based on an admission of guilt.

[17] George Fisher, Plea Bargaining's Triumph - A History if Plea Bargaining in America (Stanford University Press, Stanford California, 2003); Mike McConville and Chester L. Mirsky, Jury Trials and Plea Bargaining - A True History (Hart Publishing, Oxford 2005).

[18] Yue Ma 'A Comparative View of Judicial Supervision of Prosecutorial Discretion' 44/1 Criminal Law Bulletin (2008) p. 2.

[19] Both the Special Court for Sierra Leone and the East Timor Special Panels have rules that provide for guilty pleas. For details see Combs supra note 12, pp. 124-146.

[20] Douglas J C Thomson 'Discount of Sentencing Following a Guilty Plea' Scots Law Times (2004) 1, p. 2.

[21] U.S. Chief Prosecutor Robert Jackson, 7 June 1945, in the Report to the president printed in 
Robert Jackson, The Nürnberg Case (Cooper Square Publishers, New York, 1971) p. 10. [22] Priscilla B. Hayner 'Truth Commissions: A Schematic Overview' 88/862 International Review of the Red Cross (2006) p. 295.

[23] Richard J. Evans 'History, Memory, and the Law: The Historian as Expert Witness' 41/3 History and Theory (2002) pp. 326-345.

[24] Although the ICC has much broader jurisdiction (although limited to crimes committed after July 1 2002) or because of this it will have to make very careful decisions on which situations, which defendants and which crimes to focus.

[25] Article 7 ICTR Statute.

[26] However, the ICTY tried also a number of low-level offenders especially in the beginning when only few arrests were made.

[27] Judge Schomburg for example dissents in Deronji? because of the selection of crimes: "First, already the series of indictments, including the Second Amended Indictment, arbitrarily present facts, selected from the context of a larger criminal plan and, for unknown reasons, limited to one day and to the village of Glogova only." Prosecutor v. Deronji? (Case No. IT-02-61-S) Dissenting Opinion of Judge Schomburg (Mar. 30, 2004) para. 4.

[28] An exception is Nuremberg Charter which had also jurisdiction to declare organisations criminal (Article 9(1) Charter for the International Military Tribunal). For the debate on criminal responsibility of legal persons see Rauxloh 'A Call for the End of Impunity for Multinational Corporations' 14 Texas Wesleyan Law Review (2008) pp. 297-315.

[29] Matiangai Sirleaf 'Regional Approach to Transitional Justice? Examining the Special Court for Sierra Leone and the Truth \& Reconciliation Commission for Liberia' 21 Florida Journal of International Law (2009) 209, p. 213.

[30] Article 8 (II) Rome Statute of the International Criminal Court (U.N. Doc.A/CONF.183/9) 1998 [hereinafter Rome Statute].

[31] Article 7(I) Rome Statute.

[32] Article 6 Rome Statute.

[33] See Michela Miraglia 'Admissibility of Evidence, Standard of Proof, and Nature of the Decision in the ICC Confirmation of Charges in Lubanga' 6 Journal of International Criminal Justice (2008) 489.

[34] William Schabas, International Criminal Court (Cambridge University Press, Cambridge, 2007) $3^{\text {rd }}$ ed., p. 294.

[35] For example the prosecution had screened 100,000 captured documents of which about 4,000 were used as evidence. Jackson supra note 20, p. vi. Moreover, after the unconditional surrender the victorious allies had access to any evidence they considered relevant.

[36] Prosecutor v. Momir Nikoli? (Case No. IT-02-60/1-S) Sentencing Judgment (2 December 2003) para. 73.

[37] Statute of the International Criminal Tribunal for Former Yugoslavia, Report of the SecretaryGeneral pursuant to para. 2 of Security Council Resolution 808, Annex, U.N. Doc. S/25704 (1993)) [hereinafter ICTY Statute].

[38] Theresa Marie Clark 'Transplant Justice?: The Efficacy of a Purely Common Law Concept in the International Criminal Forum' 9 Buffalo Human Rights Law Review (2003) p. 75, footnote 108 
citing 'Suggestions made by the Government of the United States of America, Rules of Procedure and Evidence for the International Criminal Tribunal for the Prosecution of Persons Responsible for Serious Violations of International Humanitarian Law Committed in the Former Yugoslavia'. [39] Terry Coonan 'Prosecuting And Defending Violations Of Genocide And Humanitarian Law: The International Tribunal For The Former Yugoslavia' American Society of International Law Proceedings (1994) 239, p. 248.

[40] Statement by the President [of the ICTY] made at a Briefing to Members of Diplomatic Missions, IT/29, 11 February 1994, reprinted in V Morris and M.P. Scharf, An Insider's Guide to the International Criminal Tribunal for the former Yugoslavia, Vol. 2 (Transnational Publishers Inc, Irvington-on-Hudson, New York, 1995) 649, p. 652.

[41] "The question of the grant of immunity from Prosecution to a potential witness has also generated considerable debate. Those in favour contend that it will be difficult enough for us to obtain evidence against a suspect and so we should do everything possible to encourage direct testimony. They argue that this is especially true if the testimony serves to establish criminal responsibility of those higher up the chain of command. Consequently, arrangements such as pleabargaining could also be considered in an attempt to secure other convictions. However, we always have to keep in mind that this Tribunal is not a municipal criminal court but one that is charged with the task of trying persons accused of the gravest possible of all crimes. The persons appearing before us will be charged with genocide, torture, murder, sexual assault, wanton destruction, persecution and other inhumane acts. After due reflection, we have decided that no one should be immune from Prosecution for crimes such as these, no matter how useful their testimony may otherwise be." Statement by the President [of the ICTY] made at a Briefing to Members of Diplomatic Missions, IT/29, 11 February 1994, reprinted in V Morris and M.P. Scharf, supra note 39, p. 652.

[42] Paul R Williams and Karina M. Waller 'Coercive Appeasement: The Flawed International Response to the Serbian Rogue Regime' 36 New England Law Review (2002) 825, p. 888. [43] UN Security Council Resolution 1503 UN Doc. S/RES/1503 (2003) para. 7.

[44] The Tribunal reacted in several ways to cope with the pressure, including the withdrawal of indictments against a number of low-level defendants and the addition of twenty seven $a d$ litem judges and some amendments to the RPE. (See Hafida Lahiouel 'The Right of the Accused to an Expeditious Trial', in Essays on ICTY Procedure and Evidence in Honour of Gabrielle Kirk McDonald (Kluwer Law International, The Hague, 2000) pp. 208 et seq.

[45] Scharf supra note 7, p. 1074.

[46] Combs supra note 12, p. 92.

[47] Julian A. Cook 'Plea Bargaining at The Hague' 30 Yale Journal for International Law (2005) 473, p. 474.

[48] Namely Todorovi? and Simi?. However, in these cases it is very likely that the special circumstances, i.e. the conditions of the arrest in Todorovi? and the delaying effect of the poor health of Simi? (see below) explain these differences. Combs supra note 12, p. 92.

[49] He persecuted non-Serb civlian in his position as Police Chief and a member of the Serb Crisis Staff in Bosanski ?amac, including participating and ordering the beating and torturing of 
detainees. Initially he was charged with ten counts of crimes against humanity (persecutions on political, racial or religious grounds, expulsions, murder, inhumane acts, rape and acts of torture), - eight counts of violations of the laws or customs of war (murder, cruel treatment and humiliating and degrading treatment) and nine counts of serious violations of the Geneva Conventions of 1949 (expulsions or illegal transfers, intentional homicide, intentionally inflicting intense suffering and acts of torture or inhumane treatment). Prosecution v. Todorovi? et al. (Case No. IT-95-9-PT) Second Amended Indictment (19 November 1998).

[50] Combs supra note 12, p. 88.

[51] Crime against humanity as persecution on political, racial and religious grounds as crimes against humanity.

[52] Combs supra note 12, pp. 88-89.

[53] Prosecutor v. Todorovi? (Case No. IT-95-9/1) Transcript (4 May 2001) p. 55.

[54] Prosecutor v. Todorovi? (Case No. IT-95-9/1) Sentencing Judgment (July 4, 2001) para. 114.

[55] Prosecutor v. Todorovi? (Case No. IT-95-9/1) Sentencing Judgment (July 31, 2001) para. 81. [56] Ibid., para. 80. My italics.

[57] Scharf supra note 5, p. footnote 14.

[58] Prosecutor v. Sikirica (Case No. IT-95-8-S) Sentencing Judgment (13 November 2001).

[59] For more facts see Clark supra note 37, p. 76.

[60] Prosecutor v. Sikirica (Case No. IT-95-8-S) Sentencing Judgment (13 November 2001).

[61] Ibid., para. 148.

[62] Ibid., para. 149. My italics.

[63] Prosecutor v. Dragan Nikolic (Case No. IT-94-2) Sentencing Judgment (18 December 2003) paras. 275, 279-282.

[64] Ibid., para. 281.

[65] Ibid., para. 214.

[66] Ibid., paras. 232, 280.

[67] Prosecutor v. Momir Nikolic (Case No. IT-02-60/1-S) Sentencing Judgment (2 December 2003) para. 19, 183.

[68] Ibid., para. 156.

[69] Miroslav Deronji? was president of the Bratunac Crisis Staff and assisted in the displacement of the Muslim civilians in the Bratunac Municipality.

[70] Prosecutor v. Deronji? (Case No. IT-02-61-S) Dissenting Opinion of Judge Schomburg (30 March 2004) para. 2.

[71] Combs supra note 12, p. 98.

[72] Ibid. See also footnote 137 for references in press of victims' outrage.

[73] Combs supra note 12, p. 99.

[74] Ibid.

[75] Prosecutor v. Nikoli? (Case No. IT-02-60/1-S) Sentencing Judgment (2 December 2003) para. 67. 
[76] Anna Petrig 'Negotiated Justice and the Goals of International Criminal Tribunals- With a Focus on the Plea-Bargaining Practice of the ICTY and the Legal Framework of the ICC' 8 Chicago-Kent Journal of International and Comparative Law 1 (2008) p. 28.

[77] Scharf supra note 5, p. 1078.

[78] Prosecutor v. Nikolic (Case No. IT-02-60/1-S) Sentencing Judgement (2 December 2003) para. 145.

[79] Prosecutor v. Biljana Plav?i? (Case No. IT-00-39\&40/1) Sentencing Judgement (27

February 2003) para. 67.

[80] For factual basis see Prosecution v. Kraji?nik \& Plav?i? (Case No. IT-00-39\&40-PT) Factual Basis for Plea of Guilt (30 September 2002) para. 16.

[81] Combs supra note 6, p. 930.

[82] Prosecutor v. Plav?i? (Case No. IT-00-39\&40/ 1-S) Sentencing Judgment (27 February 2003) para. 15. This campaign resulted in the displacement of hundreds of thousands of Bosnian Muslim and Croats, mass killings, mass rapes, torture, concentration camps where people held under sub-human conditions, and the destruction of property and religious buildings.

[83] Prosecutor v. Biljana Plav?i? (Case No. IT-00-39\&40/1-S) Sentencing Judgement (27 February 2003) para. 75. [84] Ibid., para. 76.

[85] Ibid., para. 123. Her two requests for pardon to the Swedish government on April 2006 and June 2008 due to her old age and poor health were both rejected. On September 15, the ICTY granted early release after having served tow-thirds of her sentence.

[86] Prosecutor v. Biljana Plav?i? (Case No. IT-00-39\&40/1) Sentencing Judgement (27 February 2003) paras. 61 et seq., 110.

[87] Daniel Uggelberg Goldberg Plav?i? retracts war-crimes confession, 04 February 2009 <www.bosnia.org.uk/news/news_body.cfm?newsid=2544>, 1 June 2010), Swedish interview with Margaretha Nordgren <www.vi-tidningen.se/templates/ArticlePage.aspx?id=10784>, 1 June 2010.

[88] Combs supra note 6, p. 933.

[89] Prosecution v. Kraji?nik \& Plav?i? (Case No. IT-00-39\&40-PT) Factual Basis for Plea of Guilt (30 September 2002) para. 16.

[90] Petrig supra note 75, p. 16.

[91] Scharf supra note 5, p. 1080.

[92] Ibid.

[93] Prosecutor v. Erdemovi? (Case No. IT-96-22-T) Sentencing Judgment (29 November 1996) para. 20.

[94] Sienho Yee 'The Erdemovic Sentencing Judgement: A Questionable Milestone for the International Criminal Tribunal for the Former Yugoslavia 'Georgia Journal of International and Comparative Law (1997) p. 283.

[95] For example in Deronjic the presiding judge speculates why the charges are limited to a handful offences while there was prima facie evidence of much more crime. Prosecutor v. Deronji? (Case No. IT-02-61-S) Dissenting Opinion of Judge Schomburg (30 March 2004) para. 9.

[96] Prosecutor v. Nikoli? (Case No. IT-02-60/1-S) Sentencing Judgment (2 December 2003) 
para. 63.

[97] Prosecutor v. Plav?i?s (Case No. IT-00-39\&40-PT) Amended Consolidated Indictment (7 March 2002); Decision granting Prosecution's motion to dismiss counts 1, 2, 4, 5, 6, 7 and 8 of the amended consolidated indictment (20 December 2002).

[98] Blagoje Simi?, Simo Zari?, Miroslav Tadi?, Slobodan Miljkovi? and Stevan Todorovi?. Prosecution v Blagoje Simic et al. (Case No. IT-95-9) Second Amended Indictment (11 December 1998). Milan Simi? was initially indicted with Todorovi? and four other co-defendants. He was a member of the Bosnian Serb crisis staff and president of the municipal assembly of Bosanski ?amac. For his actions from September 1991 to February 1993 he was charged with one count of persecution as crimes against humanity, two counts of torture as crimes against humanity, two counts of inhumane acts as crimes against humanity and two counts of cruel treatment as violations of the laws or customs of war. Prosecution v. Blagoje Simic et al., (Case No. IT-95-9) Fourth Amended Indictment (11 December 1998).

[99] Combs supra note 12, p. 91.

[100] Prosecutor v. Momir Nikoli? (Case No. IT-02-60/1-S) Sentencing Judgement (2 December 2003) para. 65.

[101] An example for a case where of charge bargaining resulted in withdrawal of the genocide charge is Prosecutor v. Obrenovi? (Case No. IT-02-60/2-2) Sentencing Judgment (10 December 2003) para. 11.

[102] Interview February 2009 with the author.

[103] He was a soldier in the $10^{\text {th }}$ Sabotage Detachment of the Bosnian Serb Army (VRS) and part of the firing squad that was ordered to shoot and kill hundreds of unarmed Bosnian Muslim men who had been transported from Srebrenica. When Erdemovi? refused to participate in the killing of unarmed Muslim civilians he was threatened with instant death. He claimed that he had seen afterwards a superior ordering the killing of a soldier for disobedience. Following the orders Erdemovi? killed about seventy Muslims. When he later refused to participate in another mass killing he was shot at and wounded, Prosecutor v. Erdemovi? (Case No. IT-96-22-T) Sentencing Judgement (29 November 1996) paras. 78-81. For details on the background of the case see Yee supra note 93, p. 264.

[104] Prosecutor v. Erdemovi? (Case No. IT-96-22) Indictment (29 May 1996) para. 16.

[105] Prosecutor v. Erdemovi? (Case No. IT-96-22-T) Sentencing Judgment (29 November 1996) para. 5.

[106] Ibid.

[107] While in common law systems the guilty plea ends the proceedings in civil law countries an admission of guilt is simply part of the evidence to be considered and evaluated by the court and has no procedural effect as such.

[108] "The Appeals Chamber finds nothing in the Statute or the Rules, nor in practices of international institutions or national judicial systems, which would confine its consideration of the appeal to the issues raised formally by the parties. The preliminary issues revolve around the question of the validity of the plea of guilty entered by the Appellant." Prosecutor v. Erdemovi? (Case No. IT-96-22-A) Appeals Chamber Judgment (7 October 1997) para. 16. [109] Yee supra note 93, p. 268.

[110] Prosecutor v. Erdemovi? (Case No. IT-96-22-A) Joint Separate Opinion of Judge

McDonald and Judge Vohrah (7 October 1997) para. 2.

[111] Ibid., para. 2.

[112] Article 21 (4) of the Statute for the ICTY lists the minimum due rights of defendants:

(a) to be informed promptly and in detail in a language which he understands of the nature and 
cause

of the charge against him;

(b) to have adequate time and facilities for the preparation of his defence and to communicate with

counsel of his own choosing;

(c) to be tried without undue delay;

(d) to be tried in his presence, and to defend himself in person or through legal assistance of his own

choosing; to be informed, if he does not have legal assistance, of this right; and to have legal assistance assigned to him, in any case where the interests of justice so require, and without payment by him in any such case if he does not have sufficient means to pay for it;

(e) to examine, or have examined, the witnesses against him and to obtain the attendance and examination of witnesses on his behalf under the same conditions as witnesses against him;

(f) to have the free assistance of an interpreter if he cannot understand or speak the language used in

the International Tribunal;

(g) not to be compelled to testify against himself or to confess guilt.

[113] Prosecutor v. Erdemovic (Case No. IT-96-22-A) Separate and Dissenting Opinion of Judge Cassese (7 October 1997) para. 9.

[114] Ibid., para. 10.

[115] Prosecutor v. Erdemovi? (Case No. IT-96-22-A) Joint Separate Opinion of Judge

McDonald and Judge Vohrah (19 November 1997) paras. 8, 10.

[116] Prosecutor v Erdemovi? (Case No. IT-96-22-A ) Joint Separate Opinion of Judge

McDonald and Judge Vohrah (19 November 1997) para. 10.

[117] Ibid., para. 15.

[118] Prosecutor v. Erdemovi? (Case No. IT-96-22-T) Transcript of Initial Appearance (31 May 1996) para. 20. Rule [62ii] explicitly requires that the Chamber call upon the accused to make a plea as to each count, but it does regulate the situation where alternative charges have been made. [119] Prosecutor v. Erdemovi? (Case No. IT-96-22-A) Joint Separate Opinion of Judge McDonald and Judge Vohrah (19 November 1997) para. 18.

[120] Prosecutor v. Erdemovi? (Case No. IT-96-22-T) Transcript of Initial Appearance (31 May 1996) para. 25.

[121] Ibid., p. 26.

[122]Prosecutor v. Erdemovi? (Case No. IT-96-22-Tbis) Sentencing Judgement (5 March 1998) para. 14.

[123] For a detail comment on the question of defences in this case see Yee supra note 93, p. 286.

[124] Prosecutor v. Erdemovic (Case No. IT-96-22-A) Separate and Dissenting Opinion of Judge Cassese (7 October 1997) para. 10.

[125] Prosecutor v. Erdemovi? (Case No. IT-96-22-Tbis) Sentencing Judgement (5 March 1998) para. 25.

[126] Rule 62bis ICTY Rules of Procedure and Evidence reads: "If an accused pleads guilty in accordance with Rule 62 (vi), or requests to change his or her plea to guilty and the Trial Chamber is satisfied that: (i) the guilty plea has been made voluntarily; (ii) the guilty plea is informed; (iii) the guilty plea is not equivocal; and (iv) there is a 
sufficient factual basis for the crime and the accused's participation in it, either on the basis of independent indicia or on lack of any material disagreement between the parties about the facts of the case, the Trial Chamber may enter a finding of guilt and instruct the Registrar to set a date for the sentencing hearing."

[127] Cook supra note 46, p. 482.

[128] Prosecutor v Plav?i? (Case No. IT-00-39 \& 40-PT) Plea Transcript (2 October 2002) p. 338.

[129] Prosecutor v. ?e?i? (Case No. IT-95-10/1-PT) Plea Agreement (8 October 2003) para. 3. [130] Prosecutor v. ?e?i? (Case No. IT-95-10/1-5) Sentencing Judgment (11 March 2004) para. 111.

[131] Prosecutor v. ?e?i? (Case No. IT-95-10/1-PT) Plea Transcript (8 October 2003).

[132] Cook supra note 46, p. 485.

[133] Judge Orie "Mr. Cesic, the Trial Chamber now has to satisfy itself that your guilty plea on all 12 counts has been made voluntarily, that no threats or no coercion was exercised upon you, and that you were informed about the content of your plea. We already discussed it at some length in the previous stages of this hearing. The Trial Chamber has also to satisfy itself that the guilty plea is not equivocal. And finally, the Trial Chamber has to satisfy itself that the guilty plea finds a sufficient factual basis for the crime and the accused's participation therein. So your participation therein. We have dealt with you being -- the plea being informed. We have dealt with the free will on which you based your guilty pleas. I think by explaining and trying to find out what your understanding of the plea is and whether this is the same understanding as the understanding of the Prosecution of the charges brought against you, that whether the plea is or is not equivocal has been dealt with also." Prosecutor v. ?e?i? (Case No. IT-95-10/1PT) Plea Transcript (8 October 2003) pp. 91-92.

[134] Ibid., p. 86.

[135] Ibid., p. 63.

[136] Ibid., p. 70.

[137] "JUDGE ORIE: Yes. As far as the entering into this agreement from your own to this plea agreement? Voluntarily, not being forced or threatened or in whatever way? THE ACCUSED: [Interpretation] Yes, Your Honour." Prosecutor v. ?e?i? (Case No. IT-95-10/1-PT) Plea Transcript (8 October 2003) pp. 71-72.

[138] Ibid., p. 71.

[139] Prosecutor v. Mr?a (Case No. IT-02-59) Amended Indictment (4 August 2003) paras. 1-15. As a member of the special Bosnian Serb police unit "Intervention Squad" Darko Mr?a was accused of personally and directly participating in the unloading, guarding, escorting, shooting and killing of more than 200 unarmed men at Kori?anske Stijene.

[140] Prosecutor v. Mr? a (Case No. IT-02-59) Sentencing Judgment (31 March 2004), paras. 3-4. Following the Prosecution's sentence recommendation of between fifteen to twenty years he was sentenced in March 2004 to seventeen years imprisonment. Ibid para. 129.

[141] "Mr. Mrdja, I went through the plea agreement on the main lines. Is there anything that is not clear to you in respect of this agreement? Is there anything you would like to say adding to this agreement between you and the Office of the Prosecution? THE ACCUSED: [Interpretation] Your Honour, everything is clear to me."

Prosecutor v Mr? a (Case No. IT-02-59) Plea Transcript (24 July 2003) p. 86.

[142] "For example, that you would defend yourself, that you would call witnesses, that you would examine witnesses, that you would prepare for such a defence, that the right to remain silent, which is often invoked by those who stand trial, that by entering a different plea, of course, 
you give up that right." Prosecutor v. Mr?a (Case No. IT-02-59) Plea Transcript (24 July 2003) pp. 85-86.

[143] Milan Babi? acted first as leader of the government of the self-declared Serbian Autonomous Region (SAO) Krajina and then as President of the Republic of Serbian Krajina (RSK) in north-eastern Croatia. For his active support of the 'ethnic cleansing' campaign he was charged with crimes against humanity. For details of the facts see Prosecutor v. Babi? (Case No. IT-03-72-I) Factual Statement, Tab 1 (22 January 2004).

[144]Prosecutor v. Babi? (Case No. IT-03-72-I) Plea Transcript (27 January 2004) paras. 30-45. [145]Ibid., para. 45.

[146] Cook supra note 46, p. 492.

[147] Combs supra note 12, p. 120. Another reason suggested is that some defence lawyers coming from developing countries have no incentive preventing a trial that would be very lucrative for them.

[148] Combs supra note 12, p. 73.

[149] Ibid., p. 72.

[150] ICTR Rules of Procedure and Evidence, U.N. Doc. ITR/3/Rev.1 (1995).

[151] Modelled on Rule 62 bis of the ICTY-RPE Rule 62 B ICTR-RPE provides that 2 the Trial Chamber shall satisfy itself that the guilty plea: (i) is made freely and voluntarily; (ii) is an informed plea; (iii) is unequivocal; and (iv) is based on sufficient facts for the crime and accused's participation in it, either on the basis of objective indicia or of lack of any material disagreement between the parties about the facts of the case.

[152] Prosecutor v. Kambanda (Case No. ICTR-97-23-S) Judgment and Sentence (4 September 1998) para. 3.

[153] Prosecutor v. Rutaganira (Case No. ICTR-95-1C-I) Minutes of Proceedings (8 December 2004) para. 42.

[154] Prosecutor v. Kambanda (Case No. ICTR-97-23-S) Judgment and Sentence (4 September 1998) para. 47.

[155] Ibid., para. 48.

[156] Prosecutor v. Kambanda (Case No. ICTR-97-23-I) Transcript (3 September 1998) p. 33.

[157] Prosecutor v. Kambanda (Case No. ICTR 97-23-S) Judgment and Sentence (4 September 1998) para. 62.

[158] Ibid., para. 61(B) (v)-(vii). These factors are i.e. that (i) the crimes for which Jean

Kambanda is responsible carry an intrinsic gravity, and their widespread, p.rocious and systematic character is particularly shocking to the human conscience; (ii) Jean Kambanda committed the crimes knowingly and with premeditation; (iii) and, moreover, Jean Kambanda, as Prime Minister of Rwanda was entrusted with the duty and authority to protect the population and he abused this trust.

[159] Combs supra note 12, p. 104.

[160] Even if not as low as the two years the defence had suggested.

[161] Combs supra note 12, p. 103.

[162] Prosecutor v. Plav?i? (Case No. IT-00-39\&40/ 1-S) Sentencing Judgment (27 February 
2003) para. 53.

[163] Ibid., para. 80.

[164] Prosecutor v. Kambanda (Case No. ICTR-97-23-A) Appeal Judgment (19 October 2000) para. 3.

[165] Ibid., para. 10.

[166] Prosecutor v. Kambanda (Case No. ICTR-97-23-A) Judgment (19 Oct. 2000) para. 126.

[167] Combs supra note 12, p. 122. Defendants also doubt the impartiality of the Court as no member of the RPF has been charged.

[168] Prosecutor v. Serushago (Case No. ICTR-98-39-S) Sentence (5 February 1999). Omar

Serushago was the leader of a small group of militia who controlled a roadblock where Tutsis were detained and killed. He himself admitted having killed four people.

[169] Prosecutor v. Serushago (Case No. ICTR-98-39-S) Sentence (5 February 1999) para. 34.

[170] Ibid., para. 4.

[171] Prosecutor v. Kambanda ( Case No. ICTR-97-23-S) Judgment and Sentence (Sept. 4, 1998) para. 60;

Prosecutor v. Akayesu (Case No. ICTR-96-4-T) Sentence (2 October 1998); Prosecutor v. Kayishema \&

Ruzindana (Case No. ICTR 95-1-T) Judgment, Sentence (21 May 1999) para. 25.

[172] Prosecutor v. Serushago (Case No. ICTR-98-39) Transcript, paras. 10-12, 15.

[173] Prosecutor v. Serushago (Case No. ICTR-98-39-S) Sentence (5 February 1999) paras. 3140.

[174] Ibid., para. 42. Nonetheless, Serushago appealed against the sentencing decision arguing that the sentence was excessive and that the Trial Chamber should have given more weight to the mitigating circumstances. The appeal was however dismissed. Prosecutor v. Serushago (Case No. ICTR-98-39-A) Reasons for Judgment (6 April 2000) para. 6. [175] Prosecutor v. Rutaganira (Case No. ICTR-95-1C-I) Minutes of Proceedings (8 December 2004).

[176] Prosecutor v. Rutaganira (Case No. ICTR-95-1C-T) Transcript (17 January 2005) pp. 2-3. [177] Ibid., p. 8.

[178] Ibid., p. 29.

[179] Prosecutor v. Rutaganira (Case No. ICTR-95-1C-T) Judgment and Sentence (14 March 2005).

[180] Combs supra note 12, p. 112.

[181] Combs supra note 12, p. 113. See also Prosecutor v. Rutaganira (Case No. ICTR-95-1C-T)

Transcript (17 January 2005) p. 8.

[182] Prosecutor v. Ruggiu (Case No. ICTR-97-32-I) Judgment and Sentence, para. 53.

[183] Ibid., para. 55.

[184] Ibid. "It is important to encourage all those involved in crimes committed in Rwanda in 1994 to confess and admit their guilt."

[185] Rwanda Unhappy with Ruggiu Sentence, Hirondelle News Agency, June 1, 2000

<www.hirondelle.org/hirondelle.nsf/caefd9edd48f5826c12564cf004f793d/c319ac23033fce1ac1256

721007ae237> 1 June 2009.

[186] Also the prospect of having the case transferred to the Rwandan national courts which has the death penalty (and defendants fear transfer to Rwanda out of fear of violence). See Combs supra note 12, p. 117. 
[187] Combs supra note 12, p. 118. Combs research found also other explanation for the reluctance to plead guilty at the ICTR. One is that many defendants are infected HIV so that a sentence reduction might still in fact mean a life imprisonment for them. Further while the trial is going on defendants are detained at the United Nations Detention Facility (UNDF) which is more comfortable and provides medical treatment whereas after trial on conviction defendants are often sent to African prisons of lower comfort and less high standard of medical treatment. Since time served waiting for trial will be discounted from the sentence after is wise to spend as much time at the UNDF with a chance of acquittal. See Combs supra note 12, p. 121.

[188] Ibid., p. 119.

[189] Ibid., p. 118.

[190] Ibid., p. 148.

[191] Ibid., p. 119.

[192] Ibid.

[193] Salvatore Zappalà 'Symposium: How to Ameliorate International Criminal Proceedings:

Some Constructive Suggestions- Forward’ 5 Journal of International Criminal Justice (2007) p. 346.

[194] Faster Justice for the Balkans, N.Y. TIMES, 28 November 2003, p. A30.

[195] Scharf supra note 7, p. 1071.

[196] And other international or hybrid courts.

[197] For example whether a certain atrocity is to be classified as genocide or to what extent the defence of duress is recognised.

[198] Article 65 (1) (Proceedings on an admission of guilt) reads: "Where the accused makes an admission of guilt pursuant to article 64, paragraph 8 (a), the Trial Chamber shall determine whether:

a) The accused understands the nature and consequences of the admission of guilt;

b) The admission is voluntarily made by the accused after sufficient consultation with defence counsel; and

c) The admission of guilt is supported by the facts of the case that are contained in:

i) The charges brought by the Prosecutor and admitted by the accused;

ii) Any materials presented by the Prosecutor which supplement the charges and which the accused accepts; and

iii) Any other evidence, such as the testimony of witnesses, presented by the Prosecutor or the accused.

[199] Prosecutor v. Nikoli? (Case No. IT-02-60/1-S) Sentencing Judgment (2 December 2003) para. 52.

[200] § 257c German Criminal Procedure Code.

(1) The Court can communicate in appropriate cases with the parties in accordance with the following paragraphs about the process and outcome of the proceedings. $\S 244$, paragraph 2 shall remain unaffected.

(2) Subject of this agreement may only be those legal consequences that may be content of the judgement, corresponding court decisions and other procedural measures of the adjacent case and the process behaviour of the parties. Part of any agreement is to be a confession. The guilty verdict and measures of reform and safeguarding may not be the subject of an agreement.

(3) The Court announces the content that an understanding might have. Under the free assessment of 
all circumstances of the case and the general sentencing considerations the Court might also specify an upper and lower limit of sentence. The parties have the opportunity to make a representation. The agreement comes into force when defendant and prosecutor agree to the proposal of the court.

(4) The binding of the Court in an agreement does not apply if legally or factually significant circumstances have been overlooked or have developed since and the Court concludes therefore that the prospective punishment is no more appropriate. The same applies if the consequent process behaviour of the accused does not conform to the behaviour on which the Court's prognosis was based. In these cases the confession of the accused may not be used. The court must inform any deviation immediately.

(5) The accused shall be informed of the requirements and consequences of a deviation from the Court's contemplated of the result under paragraph 4. (Translation of the author).

[201] Prosecutor v. Nikoli? (Case No. IT-02-60/1-S) Sentencing Judgment (2 December 2003) para. 52.

[202] Regarding hybrid courts it would be necessary to examine in how far the procedure of plea bargaining is in congruence with the national systems.

[203] Article 65 Rome Statute.

[204] Hans-Peter Marsch 'Grundregeln bei Absprachen im Strafverfahren' Zeitschrift für Rechtspolitik (2007) p. 220. 